\title{
Republican Loyalist: James F. Wilson and Party Politics, 1855-1895
}

\section{LEONARD SCHLUP}

ONE OF THE FOUNDING FATHERS of Iowa Republicanism, James F. Wilson (1828-1895) represented his party and his state in the United States House of Representatives from 1861 to 1869 and the United States Senate from 1882 to 1895. A number of his contemporaries have been the subjects of excellent studies, and various memoirs and autobiographies have helped to illuminate certain personalities and events of the period. ${ }^{1}$ Yet Wilson's political career has received comparatively little notice. In the accounts of his contemporaries, he appears in scattered references to isolated fragments of his life, while the general surveys of Iowa history either ignore him or mention him only briefly. ${ }^{2} \mathrm{He}$ deserves better treatment. This essay sketches the outlines of Wilson's political career and suggests his role as conciliator in Iowa's Republican party politics. I hope the essay will help readers see Wilson's political career in a broader perspective

1. See, for example, Dan Elbert Clark, Samuel Jordan Kirkwood (Iowa City, 1917); John Ely Briggs, William Peters Hepburn (Iowa City, 1919); Edward Younger, John A. Kasson (Iowa City, 1955); Johnson Brigham, James Harlan (lowa City, 1913); Fred E. Haynes, James Baird Weaver (Iowa City, 1919); Leland L. Sage, William Boyd Allison (Iowa City, 1956); and Stanley P. Hirshson, Greenville M. Dodge (Bloomington, IN, 1967).

2. In some cases, "Jefferson Jim" Wilson has even been confused with "Tama Jim" Wilson, an Iowa farmer and Republican congressman who served as U.S. secretary of agriculture from 1897 to 1913.

THE ANNALS OF IOWA 52 (Spring 1993). CThe State Historical Society of Iowa, 1993. 
and will motivate someone to fill in the details of this sketch. ${ }^{3}$

BORN IN OHIO, Wilson was ten years old when he began working as an apprentice in his uncle's harnessmaking shop in order to assist in the support of his mother and her three other children. While engaged in this trade, he attended school and read law. Wilson completed his legal studies under William B. Woods, later an associate justice of the United States Supreme Court, and gained admittance to the bar in 1851. In the spring of 1853 he relocated to Fairfield, Iowa, where he entered into partnership with Daniel P. Stubbs. ${ }^{4}$

A free soiler opposed to the further extension of slavery, Wilson in 1854 joined the new Republican party, a coalition of Conscience Whigs, Free Soilers, and antislavery Democrats. He saw the party as a vehicle for change that would move the nation in a different direction. His views on protective tariffs, internal improvements, railroad grants, and homestead aid coincided with those of Republican nationalism, and he endorsed John C. Frémont for the presidency in $1856 .^{5}$

Wilson's political career accelerated rapidly. In February 1856 he was one of nine delegates from Jefferson County who met in the Old Stone Capitol at Iowa City to organize the Republican party in Iowa. A year later, Wilson participated in the convention at Iowa City for the revision of the state's constitution, serving on eight committees and chairing

3. Most of Wilson's papers were lost or destroyed. In 1956 a small but valuable miscellaneous collection of letters and newspaper clippings was found in the Fairfield Public Library. These items were microfilmed in 1959. The microfilm of four scrapbooks and sixty letters, covering the period from 1863 to 1895 (hereafter referred to as the Wilson Papers), is at the State Historical Society of Iowa in Iowa City.

4. Fairfield Daily Ledger, 23, 24 April 1895; lowa State Register, 23, 24 April 1895. Brief sketches of Wilson appear in standard sources such as the Dictionary of American Biography and Biographical Directory of the American Congress. See also Portrait and Biographical Album of Jefferson and Van Buren Counties, Iowa (Chicago, 1890), 169.

5. David S. Sparks, "The Birth of the Republican Party in Iowa, 18541856," Iowa Journal of History and Politics 54 (1956), 1-34. 
the one on state debts. He also gained his first political office in 1857 as a member of the lower house of the Iowa General Assembly and became chairman of the Committee of Ways and Means. In 1859 Wilson won a seat in the Iowa Senate, where he helped to revise the state code and served briefly as president pro tempore. In May 1860 Wilson joined the Iowa delegation to the Republican National Convention, which nominated Abraham Lincoln of Illinois for the presidency. During these years Wilson formed invaluable alliances with other prominent Iowa Republicans, such as Samuel J. Kirkwood, James Harlan, John A. Kasson, Grenville M. Dodge, James B. Weaver, John H. Gear, William P. Hepburn, and William B. Allison. Some of those alliances, most notably those with Dodge and Allison, lasted a lifetime and provided critical support for his political career. ${ }^{6}$

IN 1860 Wilson entered the United States House of Representatives to fill the unexpired term of Samuel R. Curtis. He immediately took a seat on the Judiciary Committee and remained there throughout the entire term of his service in the House from 1861 to 1869 ; for six years he chaired the committee. Wilson's presence in the lower chamber attracted the attention of the powerful Republican congressman from Maine, James G. Blaine, who described the Iowan as "a man of positive strength, destined to take a very prominent part in legislative proceedings."

6. Ibid.; Clark, Samuel Jordan Kirkwood, 87-89; Briggs, William Peters Hepburn, 23-25; Louis Pelzer, "The Origin and Organization of the Republican Party in Iowa," Iowa Journal of History and Politics 4 (1906), 487-525; Dubuque Daily Republican, 15 January, 1, 26 February 1856; Iowa Citizen (Des Moines), 29 June 1859; Younger, John A. Kasson, 104-20; Erik M. Eriksson, "The Framers of the Constitution of 1857," Iowa Journal of History and Politics 22 (1924), 52-88; Joseph Frazier Wall, lowa: A Bicentennial History (New York, 1978), 99-105; Iowa State Register, 23 May 1860; James F. Wilson, "Some Memories of Lincoln," North American Review 143 (December 1896), 667-75; James F. Wilson to Abraham Lincoln, 21 January 1862, 19 June 1863, Abraham Lincoln Papers, Library of Congress, Washington, DC.

7. James G. Blaine, Twenty Years of Congress, 2 vols. (Norwich, CT, 18841886), 1:332. 
Upon the outbreak of the Civil War, Wilson went on record in opposition to secession and in support of President Lincoln. A sanguine supporter of the government throughout the struggle, the Iowa Republican favored relentless military operations against the Confederates. "The surest way to a speedy peace lies in a united people in the loyal states and a vigorous prosecution of the war," he informed a Fairfield constituent. He added that the "Union must be restored as an entirety, and it will be done.... I will advocate such measures as will subdue and crush out the present infernal rebellion." 8

During the war Wilson sponsored legislation to embody the principles of civil and political equality in the nation's statutes. His first resolution called for prohibiting United States forces from returning fugitive slaves to their masters. He also presented a bill for the enfranchisement of AfricanAmericans residing in the District of Columbia and introduced a resolution to confirm the Emancipation Proclamation. In addition, Wilson was one of the earliest advocates of amendments to the Constitution to abolish slavery, grant citizenship to former slaves, and permit adult black male suffrage. ${ }^{9}$

Other events marked Wilson's wartime years in the House. He voted for the Morrill Land Grant Act of 1862, the Homestead Act of 1862, and the greenback legislation that year for financing the war. ${ }^{10}$ Yet he opposed the act providing for a system of national banks. Because Wilson was aligned with Fairfield banking interests, he voted with the eastern

8. Wilson to C. Negus, 23 February 1863, Wilson Papers.

9. Wilson's speeches on emancipation (19 March 1864), civil rights (1 March and 12 December 1883), and suffrage in the nation's capital (10 January 1866) showed his commitment to civil and political rights for African-Americans. See also Anne C. Rose, Victorian America and the Civil War (New York, 1992); William E. Gienapp, The Origins of the Republican Party (New York, 1987); and Michael Perman, The Road to Redemption: Southern Politics, 1869-1879 (Chapel Hill, NC, 1984).

10. Leland L. Sage, A History of lowa (Ames, 1974), 160-62; Leonard P. Curry, Blueprint for Modern America: Nonmilitary Legislation of the First Civil War Congress (Nashville, 1968), 197-206. 
members of Congress who felt pressure from state banks that complained of competition from national banks. ${ }^{11}$

The defeat of the Confederacy and the death of Lincoln in 1865 signaled a turning point in American history. The immediate postwar years, a time of intense partisanship and vituperation, were dominated by Reconstruction policies. Wilson argued in favor of military reconstruction to promote justice and uphold Republican supremacy in the South-a new order to be based on a political alliance of native white loyalists and freed African-American voters. A former Whig, Wilson was a congressional reconstructionist who emphasized legislative supremacy and the power of Congress over executive authority in the restoration of the seceded states. $\mathrm{He}$ also opposed judicial review of military reconstruction. ${ }^{12}$

The Civil War expanded presidential authority at the expense of legislative power. Had Lincoln lived, Radical Republicans, a group desiring a harsh policy of revenge against the defeated South, never would have given him a free hand to adopt an altruistic course leading toward reconciliation. Fate intervened by elevating Andrew Johnson to the presidency at a crucial moment. Johnson, a tactless southern politician, had been placed on the National Union ticket in 1864. He became president after Lincoln was assassinated in 1865. Ultimately, presidential obstruction of Radical legislation widened the breach between Congress and Johnson. The Radical sweep in the congressional election of 1866 increased their power to override Johnson's vetoes and invade the executive realm by interfering with presidential appointments. Under the provisions of the nebulous Tenure of Office Act of 1867, which Wilson had helped to draft, the president was prohibited from removing appointed officials confirmed by the Senate without first obtaining the Senate's approval. When on August 12, 1867, Johnson suspended Secretary of War Edwin M. Stanton and temporarily replaced him with General Ulysses S. Grant, a seemingly routine presidential

11. Wilson would later become president of the First National Bank of Fairfield.

12. Earle D. Ross, "James F. Wilson, Legalistic Free-Soiler," Annals of Iowa 32 (1954), 365-75. 
prerogative, the Senate refused to concur. The controversial result was Stanton's reinstatement. ${ }^{13}$

By 1867 , politically motivated Radicals wished to remove Johnson from office. On November 25 a majority of the House Judiciary Committee reported a resolution of impeachment. Wilson, chairman of that committee, opposed impeachment and shepherded his followers through trying times, reminding colleagues that specific violations of the law were mandatory for an indictable offense and a successful prosecution in the upper chamber. Wilson filed his minority report on November 25 and then concentrated on legal issues in an address to the House on December 6. The next day the House rejected the majority resolution. Wilson rejoiced in this decision; his political centrism had triumphed over Radical extremism. "I did what seemed to me a duty, and shall not quarrel with the consequences," he explained to a Burlington editor. ${ }^{14}$

The accusations against the president probably would have ended in 1867 had Johnson not forced the issue by formally removing the redoubtable Stanton on February 21, 1868. He replaced him as secretary of war ad interim with General Lorenzo Thomas, without submitting Thomas's name to the Senate for approval. The upper chamber refused to confirm Thomas. This time Wilson changed sides, becoming a Radical centrist. Believing that Johnson had thrown down the gauntlet to Congress and that he was now guilty of criminally violating a statute, Wilson argued that the president had a responsibility to obey acts of Congress regardless

13. George B. Corkhill to Wilson, 20 July 1866, Wilson Papers; Harry James Brown and Frederick D. Williams, eds., The Diary of James A. Garfield, 4 vols. (East Lansing, MI, 1967-1981), 1:428.

14. New York Herald, 21 October 1867; Hans L. Trefousse, Andrew Johnson: A Biography (New York, 1989), 301-3; John Sherman, Recollections of Forty Years in the House, Senate and Cabinet: An Autobiography, 2 vols. (Chicago, 1895), 1:413-14; Congressional Globe, 40th Cong., 2d sess., 6 December 1867, pp. 62-65; David Miller DeWitt, The Impeachment and Trial of Andrew Johnson (1903; reprint ed., Madison, WI, 1967, 302-13; Michael Les Benedict, A Compromise of Principle (New York, 1974), 286-314; idem, The Impeachment and Trial of Andrew Johnson (New York, 1973), 80-81, 109-14; Wilson to Editor of Burlington Hawk-Eye, 21 December 1867, Wilson Papers. 
of his opinion as to their validity. ${ }^{15}$ This was his stated reason, but Wilson also disagreed with Johnson's political outlook and his administration of the Reconstruction acts.

Wilson reluctantly supported impeachment in 1868 because he wanted to invoke a constitutional safeguard against presidential inviolability and to preserve peace and order. ${ }^{16}$ Concluding that it had been a mistake to nominate Johnson for vice-president, Wilson berated Lincoln's successor as one who had succumbed to political apostasy. Wilson's conversion was a tough decision based on a moral choice. ${ }^{17}$ "I will vote for the pending resolution," he confessed, "to the end that the law may be vindicated by the removal of an unworthy public servant from an official position, which he has dishonored by his perverse disregard of duty and his unjustifiable contempt for the supremacy of the law."18

By a vote of 126 to 47 , the House impeached Johnson on February 24, 1868, for "high crimes and misdemeanors" but neglected to specify their exact nature. To that end, House Speaker Schuyler Colfax appointed seven members, including Wilson, to draft articles of impeachment. The Republican representatives also elected seven managers or prosecutors to present the articles to the Senate. This board consisted of Radicals such as Thaddeus Stevens and moderates such as Wilson. On March 4 they presented to the Senate eleven articles of impeachment. ${ }^{19}$

15. Benedict, A Compromise of Principle, 309.

16. Similar arguments were used in the 1970 s and 1980 s in connection with Watergate and Iran-Contra, two scandals of extraordinary proportions based on unconstitutional actions that far surpassed anything Johnson had done.

17. Congressional Globe, 40th Cong., 2d sess., 24 February 1868, p. 1386; Brooks D. Simpson, Let Us Have Peace: Ulysses S. Grant and the Politics of War and Reconstruction, 1861-1868 (Chapel Hill, NC, 1991), 243.

18. Blaine, Twenty Years of Congress, 2:358.

19. George S. Boutwell, "The Impeachment of Andrew Johnson," McClure's Magazine 14 (December 1899), 171-82; House Reports, 40th Cong., 1st sess., no. 7, "Impeachment of the President," 59-105; Ben Perley Poore to W. W. Clapp, 27 May 1868, William W. Clapp Papers, Library of Congress; George W. Fish to Austin Blair, 3 March 1868, Austin Blair Papers, Detroit Public Library; John Bingham to Mrs. Bingham, 16 February 1868, John A. Bingham Papers, Ohio Historical Society Library, Columbus. 
Because the vice-presidency was vacant, Senator Benjamin F. Wade, an Ohio Republican and president pro tempore of the Senate, was next in line of succession. Disliked by moderates for his Radical stand and abhorred by many business leaders for his high tariff and soft money views, Wade apparently appealed to Wilson, who entertained no qualms about having the Radical reconstructionist occupy the Executive Mansion for the duration of the term. Yet the thought of the possible calamities of a Wade administration enhanced Johnson's chances for survival. ${ }^{20}$

Wilson introduced to the Senate the evidence gathered by the House. Gideon Welles, secretary of the Navy under Lincoln and Johnson, recorded in his diary on April 18 that Wilson's "elaborate speech" was read from a "carefully prepared manuscript." 21 After hearing from witnesses and examining the allegations, the senators voted in May, with Chief Justice Salmon P. Chase presiding. The vote of 35 for conviction and 19 for acquittal was one vote short of the two-thirds necessary. Johnson thus narrowly escaped the ignominious fate of being ousted from office, and the verdict strengthened the constitutionally mandated separation of powers.

Seven Republican senators, including James W. Grimes of Iowa, broke ranks to vote for acquittal. ${ }^{22}$ Brushing aside thoughts of political suicide, Grimes, having suffered a paralytic stroke during the proceedings, stated that he could not "destroy the harmonious working of the Constitution for the

20. Hans L. Trefousse, Benjamin Franklin Wade (New York, 1963), 261-310; T. W. Egan to Andrew Johnson, 7 October 1867, Andrew Johnson Papers, Library of Congress; B. Gratz Brown to Benjamin F. Wade, 2, 26 March 1868, Benjamin F. Wade Papers, Library of Congress.

21. Gideon Welles, Diary of Gideon Welles, 3 vols. (Boston, 1911), 3:334; New York Times, 20 May 1868.

22. Ralph J. Roske, "The Seven Martyrs?" American Historical Review 64 (1959), 323-30; Boston Evening Journal, 23 May 1868; James W. Grimes to William P. Fessenden, 16 June 1868, William Pitt Fessenden Papers, Bowdoin College Library, Brunswick, Maine. Besides Grimes, the Republicans who voted for acquittal were William P. Fessenden of Maine, Joseph S. Fowler of Tennessee, John B. Henderson of Missouri, Edmund G. Ross of Kansas, Lyman Trumbull of Illinois, and Peter Van Winkle of West Virginia. 
sake of getting rid of an unacceptable President. ${ }^{23}$ Grimes's decision troubled Congressman William B. Allison and most other Iowa Republicans in Congress, who censured him. Wilson, on the other hand, showed kindness to the venerable senator and called on him during his illness, refusing to accept the Radical denunciation of the once idolized but now enfeebled leader. Joining Wilson in this endeavor was the war hero Grenville M. Dodge, a Republican congressman from Iowa. A railroad builder and chief engineer of the Union Pacific Railroad, Dodge claimed that the entire Iowa delegation, except Wilson and himself, were "down on" Grimes. It was not surprising that Dodge and Wilson stood by Grimes. The three had long been close friends, and it was foreign to Wilson's character to disown loyal acquaintances. ${ }^{24}$

The impeachment mania that gripped the House and Senate in 1868 marked a dark chapter in American history. Too many members of Congress succumbed to the popular frenzy of the moment. They used their personal animosity against Johnson for partisan advantage. Clearly, under a parliamentary system of government, Johnson would have resigned upon a legislative vote of no confidence. Although the presidential system of checks and balances operated dif-. ferently, Johnson's term of office would have ended in less than a year. Yet these impatient men went after the embattled chief executive by using, among others, an ambiguous law that later was modified, in large part repealed, and ultimately declared unconstitutional by the Supreme Court. It was an encroachment on the executive branch of government, but Wilson, an expert on constitutional law, never comprehended that fact.

23. Quoted in William H. Rehnquist, Grand Inquests: The Historic Impeachments of Justice Samuel Chase and President Andrew Johnson (New York, 1992), 243.

24. William Salter, The Life of James W. Grimes (New York, 1876), 367; Fred B. Lewellen, "Political Ideas of James W. Grimes," Iowa Journal of History and Politics 42 (1944), 339-404; Grenville M. Dodge to Horace White, 22 October 1913, Horace White Papers, Illinois State Historical Library, Springfield; Leland L. Sage, William Boyd Allison: A Study in Practical Politics (Iowa City, 1956), 86-87; Stanley P. Hirshson, Grenville M. Dodge: Soldier, Politician, Railroad Pioneer (Bloomington, IN, 1967), 160; Sage, A History of Iowa, 176-79. 
Wilson failed to recognize that conviction could have constituted a great danger to the Republicans. Extreme measures under Radical leaders not only could have resulted in a repudiation of the Republicans at the polls but also could have shattered confidence in the government and wrecked the economy. Wilson should have followed the prudent notion of the retired New Hampshire senator, George G. Fogg, who wisely counseled moderation. "Maintain things as they are and nothing can prevent Grant from being the next President," he advised Congressman Elihu B. Washburne. Instead of following such a course, Wilson, according to Senator Fessenden, departed from "his usual discretion." 25

The events surrounding the impeachment process took their toll on Wilson. He had spent nearly seven years in Congress during a tumultuous period. In 1868 Wilson decided that he had had enough, and he voluntarily retired from politics upon the conclusion of his term. In a letter to Christian Slagle, a close Fairfield friend, Wilson emphasized that he had "served my constituents and my country to the best of my humble abilities during a most troublous period of our national history."26

AFTER THE FAILURE of the Senate to convict Johnson, Wilson turned his attention to the upcoming presidential contest. Grant wanted Dodge and Wilson to look after his interests at the Republican National Convention in Chicago. Wilson enthusiastically supported Grant, who received the nomination in May, and campaigned for the ticket that fall. Wilson harbored no doubts as to Grant's victory in 1868 . "Everything portends the ... election of General Grant. The whole country will unite in a common effort to make his administration a success," he assured Slagle. ${ }^{27}$

Grant's victory over Horatio Seymour in November opened a new dimension in Wilson's life. Because of his record in Congress and close connection with Grant, Wilson

25. George G. Fogg to Elihu B. Washburne, 20 November 1867, Elihu B. Washburne Papers, Library of Congress; Ross, "James F. Wilson," 371.

26. Wilson to Christian W. Slagle, 4 April 1868, Wilson Papers.

27. Ibid. 
was considered for a Cabinet post in the new administration. Grant impulsively and maladroitly offered the secretaryship of state to Representative Elihu B. Washburne, who accepted the post temporarily on the condition that he be appointed minister to France. The imperturbable Grant tried to persuade Wilson to accept the vacant state portfolio under these unusual circumstances, but misunderstandings over the Washburne imbroglio and Washburne's distribution of patronage-compounded by Wilson's limited financial resources, which would not permit lavish entertaining-caused Wilson to decline the offer. The president "very much regretted" that Wilson "felt constrained not to accept" and reassured the Iowan that he still entertained "the same high opinion of you that I did when tendering you a Cabinet appointment." Grant thereupon selected Hamilton Fish, a former governor of New York and United States senator, for secretary of state. ${ }^{28}$

Wilson's absence from Grant's Cabinet was probably for the best. He would have been out of place in an administration filled with disreputable cronies and speculators and characterized by graft and guile. Instead, Wilson avoided this embarrassment by returning to Iowa, where he devoted his time mainly to his law practice. A buyer of securities and an effective writer and speaker, Wilson enjoyed a comfortable life in Fairfield, but he was never far removed from politics.

Although out of elective office, Wilson was too young for a hermetical existence. He served for six years under Grant as one of the government directors of the Union Pacific Railroad. During this period, he kept in close contact with prominent individuals and railroad barons. Not everything ran smoothly for the former congressman. Wilson told Dodge in 1870 that he would not ask Grant to keep him in the position if "a set of shysters" wanted him removed. "If I

28. Ulysses S. Grant to Philip H. Sheridan, 31 March 1868, Philip H. Sheridan Papers, Library of Congress; John A. Rawlins to John M. Schofield, 5 August 1868, Ulysses S. Grant Papers, Library of Congress; William B. Hesseltine, Ulysses S. Grant: Politician (New York, 1935), 14148; New York Tribune, 29 January, 12 April 1869; Grant to Hamilton Fish, 11 March 1869, Grant Papers; Grant to Wilson, 9 April 1869, Wilson Papers. 
must go through any of the influences which are trying to use the U.P. for personal ends," he added, "I will leave behind me a report that may open somebody's eyes." 29

Wilson did not entirely escape the stigma of the scandals that plagued the Grant administration. Several politicians, including Vice-President Schuyler Colfax, were discredited and had their careers wrecked by the corruption that permeated the nation in the post-Civil War years. In Wilson's case, he had been a zealous promoter of the Union Pacific Railroad, demonstrating his confidence by profitable though moderate speculation in the stock of Credit Mobilier of America, which acted as the construction company for the Union Pacific Railroad. Regrettably, Credit Mobilier sold stock in the company to legislators in return for political favors. Admitting to a House investigative committee that he had secured stock as an investment, Wilson, eager to parade his innocence, emphatically denied charges that he had received checks or retainers out of a special fund. He also solemnly insisted that he had no idea of the stock's value and had responded properly upon learning of irregular developments. In the absence of substantiating proof of any wrongdoing, Wilson managed to salvage his reputation, although hostile eastern newspapers attacked his record in the affair. ${ }^{30}$

The incident did not prove detrimental to Wilson's political base in Iowa. In fact, in light of the greed that existed in an age of materialism, his activity paled in comparison with others. Among his friends, a genuine understanding prevailed that withstood charges against his integrity. Representative Jeremiah M. Wilson, an Indiana Republican, assured his colleague from Iowa, "I do not think a single member of the committee entertained even a suspicion that you were in

29. Wilson to Dodge, 31 May 1870, Grenville M. Dodge Papers, State Historical Society of Iowa, Des Moines. Information on the Union Pacific Railroad can be found among materials in Special Collections, University of Iowa Libraries, Iowa City.

30. Claude G. Bowers, The Tragic Era (Cambridge, MA, 1929), 397; House Reports, 42nd Cong., 3d sess., 1873, p. 216; Burlington Weekly Hawk-Eye, 21 December 1871; Dodge to Wilson, 25 March, 10 May 1873, Dodge Papers. 
any way tainted in regard to any of that Credit Mobilier

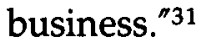

Wilson's name surfaced in 1872 as a possible vicepresidential running mate with Grant. Dodge urged William E. Chandler, a New Hampshire Republican who later served in the Senate, to "get the N. Y. Times to come out for Wilson for V. P." He suggested that Uriah H. Painter, a Philadelphia journalist, and Henry Van Ness Boynton, of the Cincinnati Gazette, should "follow up." "We want to put W. through but I want it to start in the East, ${ }^{\prime}$ Dodge added. ${ }^{32}$

Although Dodge and Allison worked to secure the vicepresidential spot for Wilson, the Iowan was not formally placed in nomination. For various reasons, the honor went to Senator Henry Wilson of Massachusetts. Because James F. Wilson belonged to the dominant party of a one-party state, he stood little chance of being selected for the national ticket. During that time, doubtful states, such as Ohio, New York, and Indiana, produced most of the presidential and vicepresidential nominees of both parties.

Wilson remained a potent force in Iowa politics. By the time of the 1872 senatorial contest, he had aligned himself with the GOP faction that opposed Senator James Harlan. Wilson's argument with Harlan had begun in 1865 when Harlan resigned from the Senate to serve in Johnson's Cabinet. Disagreements with the president soon caused Harlan to demand back his still vacant seat. Using his powerful machine to influence legislators, Harlan succeeded in his senatorial quest. In the process, however, he antagonized Samuel Kirkwood, Iowa's popular war governor, who had claims on the position. Kirkwood and his allies, including Wilson, thereupon formed an anti-Harlan group, led by Dodge and Allison, that worked tirelessly to garner sufficient support in the legislature to defeat Harlan in $1872 .{ }^{33}$ Wilson, a political

31. Jeremiah M. Wilson to Wilson, 5 August 1881, Wilson Papers.

32. Dodge to William E. Chandler, 11 January 1872, William E. Chandler Papers, Library of Congress.

33. Wall, Iowa, 157-58; Sage, A History of Iowa, 183; Johnson Brigham, James Harlan (Iowa City, 1913). A pro-Harlan faction included Elijah Sells, FitzHenry Warren, and William Penn Clarke. 
protégé of Dodge, announced his willingness to be considered for the senatorship in 1872, but his belated and less than wholehearted candidacy indirectly aided Allison, who won the seat in spite of Wilson's charge that President Grant had tried to influence the contest by giving Harlan the state's patronage. ${ }^{34}$

In 1876, Wilson favored James G. Blaine, former Speaker of the House of Representatives, for the Republican presidential nomination. Blaine's popularity with orthodox Republicans overshadowed some of his questionable public actions. The Iowa delegation consistently endorsed Blaine at the Republican National Convention in Cincinnati before jumping on the bandwagon of Governor Rutherford B. Hayes of Ohio. Having no alternative policy should Blaine be rejected, Wilson registered disappointment with the outcome, asserting that Iowans had not wanted Hayes. ${ }^{35}$

The presidential election of 1876 turned out to be the most controversial in American history, for the issue boiled down to one of legitimacy. Although Samuel J. Tilden, the Democratic nominee, accumulated more popular votes than Hayes, he lacked the 185 electoral votes needed for victory. Republicans refused to concede the election because certain disputed states submitted two sets of returns. The Democratic House and Republican Senate agreed to resolve the matter by establishing a fifteen-member electoral commission to weigh the evidence and break the deadlock. Wilson advised Allison to oppose the bill providing for this commission. "If it passes and Tilden is elected," he warned, "it will ruin any man in the Western states that voted for it." ${ }^{\prime 36}$

34. William B. Allison to Whitelaw Reid, 4 April 1872, Whitelaw Reid Papers, Library of Congress; Iowa State Register, 5 September 1871; Dan Elbert Clark, History of Senatorial Elections in Iowa: A Study in American Politics (Iowa City, 1912), 158-61; Wilson to Dodge, 19, 20 April 1871, Dodge Papers.

35. Wilson to Samuel J. Kirkwood, 23 June 1876, and Wilson to Allison, 5, 9 June 1876, William Boyd Allison Papers, State Historical Society of Iowa, Des Moines; Allison to Rutherford B. Hayes, 17 June 1876, Rutherford B. Hayes Papers, Hayes Presidential Center, Fremont, Ohio.

36. Wilson to Allison, 23 January 1877, Allison Papers. 
The commission, dominated by Republicans, voted on partisan lines for the Hayes electors, even though the evidence was clearly in Tilden's favor. Dodge and other northern Republicans persuaded southern Democratic congressmen that the construction of the Texas and Pacific Railroad hinged on a Republican victory. ${ }^{37}$ In return for Democratic support, Republicans promised to withdraw the last federal troops from the South, appoint at least one southerner to the Cabinet, and appropriate money for southern internal improvements. The compromise was accepted, and Hayes took the oath of office as president. Apparently Dodge neglected to inform Wilson of the clandestine Republican machinations and his own involvement in the Compromise of 1877. After the president had helped to remove some southern governors as part of the bargain, Wilson condemned the actions as a "blunder-if not crime." ${ }^{\text {" }} 8$

At times Wilson's vociferous criticism of Hayes implied that the Iowan had temporarily forgotten that the president was his party's head. ${ }^{39}$ Wilson also overlooked Hayes's enlightened policies designed to heal the wounds between North and South and to restore the prestige of the presidential office. Like two of his successors, Calvin Coolidge and Gerald R. Ford, Hayes showed statesmanlike qualities and moral courage in his endeavors to repair the presidency after the scandals that had disgraced his predecessor. Ironically, Hayes, a man of sterling integrity, was the beneficiary of a stolen election. Wilson's poor treatment of the president

37. Dodge to James A. Evans, 6 November 1876, and Dodge to Thomas A. Scott, 20 February 1877, Dodge Papers; Hayes to William Henry Smith, 24 December 1876, Hayes Papers; Railroad Gazette 9 (19 January 1877), 29-30.

38. Wilson to Allison, 10 April 1877, quoted in Sage, William Boyd Allison, 146-49; C. Vann Woodward, Reunion and Reaction: The Compromise of 1877 and the End of Reconstruction (Boston, 1966).

39. For example, Wilson begged Allison not to vote to confirm Hayes's nomination of John Marshall Harlan of Kentucky for the Supreme Court. Wilson considered Harlan "unfit for the place. He is not a first class lawyer and is a mere politician. For God's sake give us no more of that kind of cattle on the Supreme bench." Wilson to Allison, 31 October 1877; Sage, William Boyd Allison, 146-48. 
exhibited a behavior totally at variance with his normal pattern.

Because Hayes chose not to seek a second term, the 1880 presidential nomination was open. Desiring to find a good man who could unite the GOP, Wilson worried that the interests of individual aspirants at the convention might predominate over the welfare of the party. He emphasized that the delegates should be "for the reliable Republican who can most certainly lead us to victory. ... To this end I would sink personal preferences." Once again Wilson's personal preference was Blaine, though he would have endorsed Grant for a third term. "I want a candidate of deep earnest convictions," he expounded. "I want our party held together in harmony and I don't want any more dark horse performances." 40

At the Republican National Convention in Chicago, Iowa backed Blaine on thirty-five successive ballots. Deadlocked between Blaine and Grant, weary delegates ultimately turned to Representative James A. Garfield, senator-elect from Ohio and a member of the Half-Breed faction of the party. In spite of Wilson's wishes, Republicans repeated their earlier tactic by selecting a dark horse standard-bearer from Ohio. Like Wilson, Garfield was a moderate and a pacificator. They had long been friends since their days in Congress, and both had been grilled for their parts in the Credit Mobilier affair. Satisfied that the party was no longer in "great peril," Wilson dispatched a letter to Garfield. "I congratulate you on being the instrument of that escape," he wrote. "I cannot doubt your election." Wilson went on to predict that the GOP would "control the destinies of this Republic for an indefinite term." 41

Wilson campaigned for Garfield during the postconvention months and rejoiced upon learning of his election over Winfield S. Hancock, the Democratic challenger, and General James B. Weaver of Iowa, presidential contender of

40. Wilson to James S. Clarkson, 9 January 1880, James S. Clarkson Papers, State Historical Society of Iowa, Des Moines. See also Dodge to Wilson, 12 April 1880, Dodge Papers.

41. Wilson to James A. Garfield, 10 June 1880, James A. Garfield Papers, Library of Congress. 
the Greenback party, an organization Wilson viewed with suspicion. "What a wondrous people is ours," a delighted Wilson related to the president-elect. Noting that the electorate had committed the nation to Garfield's charge, Wilson hoped that his administration would "stand with the best." Wilson was also pleased that Joseph Warren Keifer, a Republican from Ohio, would be the next Speaker of the House of Representatives. ${ }^{42}$

Wilson's name cropped up as a Cabinet possibility in the new administration, but the Fairfield politician seemed to dismiss the idea. Writing to James S. Clarkson, editor of the Iowa State Register and member of the Republican National Committee, Wilson outlined his view on the matter. "I have no reason to believe," he stated, "that Genl Garfield has thought of me as a possible member of his cabinet.... I like the retirement, the quiet and the independence of private life. If ever I quit it for public service, it will be in answer to a call to a station in which my presence may seem to be a duty. A call to a position congenial to my tastes ... would be accorded my most earnest and conscientious consideration." 43

The congenial position soon materialized. President Garfield selected Senator Samuel J. Kirkwood of Iowa for the position of secretary of the interior, and Governor John $\mathrm{H}$. Gear of Iowa awarded the vacant senatorship to James W. McDill, a former congressman and member of the Iowa Board of Railroad Commissioners. In the meantime, Senator Allison had manipulated the political scene to Wilson's advantage. Persuaded by Allison and Dodge to reenter the political arena, Wilson announced his candidacy for the United States Senate. He proved to be an indefatigable campaigner for the seat. It was a defining moment in his political career. Although he did not long for a life in Washington, Wilson by that time wanted the status and influence of holding a senatorial position free of restricting imperatives. The day of Kirkwood's resignation from the Senate, Wilson wrote to Kirkwood, "So things have turned out! And now I have a

42. Wilson to Garfield, 5 November 1880, Garfield Papers.

43. Wilson to Clarkson, 13 November 1880, Garfield Papers. 
job on my hands. I have written to a number of persons today." 44

Wilson's alignments with Dodge and Allison were both ideological and pragmatic. Their relationship was a solid political and personal association that lasted until Wilson's death. Out of this political partnership, Wilson gained power and influence in Washington and Des Moines. While serving in the House, he had represented Dodge's interests in the nation's capital, and Dodge in turn considered Wilson "one of the most able men in the House-I think perhaps the ablest. He never fails to carry a bill he supports." ${ }^{45}$ As for Allison, Wilson remained in his mentor's shadow, never equaling the legislative distinction of his colleague, who harbored national ambitions. "Give me any suggestions you deem proper," Wilson urged Allison in 1881. "This is our fight-your future and mine." 46

Having the support of Allison, Dodge, and Kirkwood, Wilson sought advice and endorsements from others for his senatorial ambitions. The list of allies included local party leaders and bankers. He also contacted Jonathan P. Dolliver, a rising Republican star who then occupied the post of city solicitor of Fort Dodge, Iowa. Wilson asked Dolliver to serve "as an 'outlook committee' for the 'tall grass region."

In keeping with his career-long opposition to presidential involvement in state campaigns, Wilson protested against Blaine's rumored interference in Iowa politics. Yet Wilson was not above political scheming on his return road to Washington. He even sought Blaine's endorsement for his own candidacy. And he prodded Allison to work with Senator Kirkwood and Secretary of War Robert Todd Lincoln to

44. Wilson to Kirkwood, 7 March 1881, Samuel J. Kirkwood Papers, State Historical Society of Iowa, Des Moines. See also Sage, William Boyd Allison, 177.

45: Quoted in Hirshson, Grenville M. Dodge, 148.

46. Wilson to Allison, 7 March 1881, Allison Papers; Kellogg Post, 24 March 1881; Wilson to Allison, 18 March 1881, quoted in Sage, William Boyd Allison, 178-79.

47. Wilson to Jonathan P. Dolliver, 25 March, 5 April 1881, Jonathan P. Dolliver Papers, State Historical Society of Iowa, Iowa City. 
secure a foreign appointment for former Senator Harlan, thereby removing him from the senatorial competition. ${ }^{48}$

Wilson worried that his major opponent for the Senate seat, Governor Gear, would receive railroad support. Both Wilson and Gear had helped the railroads in the 1870s; in 1878 they had favored the repeal of the Iowa Railroad Act of 1874. But now, Wilson complained, "I have got to make the fight without the R. R. peoples help. I think they are all Gearish. ${ }^{49}$ On May 25, 1881, Wilson ensured their opposition when he addressed the Northwestern River Improvement Convention in Davenport. While advocating the betterment of water transportation, he assailed the railroads for stock watering and pooling, and insisted on the public character of transportation. Although newspapers and various individuals generally praised Wilson's speech, Charles E. Perkins, president of the Chicago, Burlington \& Quincy Railroad, retaliated by sending a furious letter to Allison. Perkins angrily accused Wilson of being a "cold and selfish man" and "an arrant demagogue" who was enunciating "absurd communistic theories" that were "opposed not only to his own previous record and to my interests, but equally opposed to the interests of all property rights. ${ }^{.50}$

After Republicans won a comfortable majority in the Iowa General Assembly, the stage was set for the legislators to choose the next United States senator to join Allison in Washington. Never an overconfident man, Wilson asked Dolliver to travel to Des Moines and remain there as an observer for the duration of the senatorial balloting. "I want some of my good friends from the outside to be present during the canvass," he rationalized. Wilson's worries never materialized, for Gear and other rivals withdrew their names from consideration. On January 10, 1882, in the Republican caucus, Eldin J. Hartshorn nominated Wilson, who then obtained the party's nomination by acclamation. In the for-

48. Wilson to Allison, 8 April 1881, Allison Papers.

49. Wilson to Allison, 11 March 1881, quoted in Sage, William Boyd Allison, 178.

50. Iowa State Register, 26, 27 May 1881; Charles E. Perkins to Allison, 28 May 1881, quoted in Sage, William Boyd Allison, 180. 
mal election held by the General Assembly, Wilson garnered 68 votes in the House and 42 in the Senate, easily outdistancing his Democratic opponent. On January 25, the two houses met in joint session to issue Wilson a certificate of election. Congressman Cyrus C. Carpenter thought that Wilson would "take his place among the statesmen of this century." ${ }^{\text {"1 }}$

AT THE TIME Wilson won his Senate seat, the nation was adjusting to a new administration. In 1881 the assassination of Garfield, a warmhearted but weak chief executive, catapulted Vice-President Chester A. Arthur into the presidency. Wilson did not find Arthur particularly appealing, and in 1884 he again threw his support to Blaine for the Republican presidential nomination. Blaine's defeat that fall at the hands of Grover Cleveland, the Democratic presidential nominee, upset Wilson, who had to contend with a chief magistrate of the opposition party and his distribution of patronage. ${ }^{52}$

Undeniably, Wilson's senatorial service fell below the brilliance and achievements he had rendered in the House of Representatives. For one thing, he lacked a burning cause, such as the antislavery crusade and civil rights, that had propelled him into the spotlight in the 1860s. Second, Allison was the dominant voice of Iowa Republicanism, forcing Wilson to take a back seat to the senior senator. Third, Wilson was feeling the effects of steadily failing health. Finally, Wilson was basically a pragmatic conservative rather than an ideologue. As a member of the foreign relations, education and labor, census, mines and mining, and judiciary committees, among others, he worked tirelessly but quietly on Senate business without always making headlines.

51. Wilson to Dolliver, 19 December 1881, Dolliver Papers; 1882 Iowa House Journal, 56-57; Clark, History of Senatorial Elections in Iowa, 187-99; Cyrus C. Carpenter to Dolliver, 12 January 1882, Dolliver Papers; Cyrus C. Carpenter Diary, 16 May 1881, Cyrus Clay Carpenter Papers, State Historical Society of Iowa, Iowa City; Thomas Richard Ross, Jonathan Prentiss Dolliver: A Study in Political Integrity and Independence (Iowa City, 1958), 46-47.

52. Iowa State Register, 12 June 1884; Cedar Falls Gazette, 13 June 1884; James F. Wilson, President vs. Citizen (Washington, DC, 1886), 1-17; Con8ressional Record, 49th Cong., 1st sess., 11 March 1886, pp. 2291-96. 
Several factors shaped Wilson's political outlook. Foremost among these was the fact that he practiced politics in a one-party state. This was the great determinant of Iowa's political structure at that time, and in spite of intraparty wrangling over spoils, Wilson enjoyed a degree of political security. Like other midwestern Republicans, he could count on the loyalty of manufacturers, who were attracted by the party's identification with the protective tariff, and farmers, whose Republicanism dated from the Civil War. By 1896, the Republican party had established itself as the majority party nationally. ${ }^{53}$

Wilson's postwar service occurred during the Gilded Age, encompassing the closing of the frontier, the Industrial Revolution, and the settlement of the West, among other significant events. It was an era of spoilsmen, profiteers, robber barons, and political bosses, all described brilliantly in Mark Twain's utopian satire, The Gilded Age (1873). The nation was changing from an agricultural, isolated, localized, and traditional society into an industrial, urban, national, and diverse republic. In Iowa, for example, railroads dominated the state's politics, transformed its economy, and reduced rural isolation. ${ }^{54}$

Like others who served in Congress and the executive branch during the thirty years after the Civil War, Wilson failed to recognize that the major political problem of his generation reverberated around the adjustments to the enormous economic and social transformations imposed on the United States by industrialization and urbanization. Wilson himself was a Gilded Age Hamiltonian who lived in an agrarian region at a time of tremendous change: Part liberal-progressive and part conservative, both a reformer and a conformer, he sought the security of Old Guard so-

53. Robert D. Marcus, Grand Old Party: Political Structure in the Gilded Age, 1880-1896 (New York, 1971), 4-10; Wall, Iowa, 125.

54. See Robert H. Wiebe, The Search for Order, 1877-1920 (New York, 1967); Blake McKelvey, The Urbanization of America, 1860-1915 (New Brunswick, NJ, 1963); Paul Kleppner, The Third Electoral System, 1853-1892 (Chapel Hill, NC, 1979). 
ciety but often expressed dissenting opinions on various issues. $^{55}$

Most of his Senate speeches dealt with tariff protection, government and railroads, farmers, federal elections, and interstate commerce. On these and other issues, Wilson sought to enhance the national position of the Republican party. He was a framer of the Interstate Commerce Act of 1887, which set up a commission to regulate the business operations, services, and rates of interstate carriers. Along with a majority of Iowa Republicans, he favored protective tariffs and bimetallism. This policy permitted high duties on certain items to protect American industries and the use of both gold and silver as circulating mediums to provide for a stable currency. Because agriculture dominated the economic scene in Iowa, Wilson always carefully weighed tariff legislation with an eye for his constituents and to this extent marshalled his arguments effectively. ${ }^{56}$

Wilson did not overlook other matters. He devoted much of his time to prohibition, the main social issue of the $1880 \mathrm{~s}$. A zealous teetotaler and a member of the Sons of Temperance, he sought to commit the GOP to temperance reform. The issue divided Iowa Republicans. Old party stalwarts such as Kirkwood and Gear opposed the movement while Clarkson allied himself with the prohibitionists. Allison, a master of vague statements and straddling double-talk, tried to avoid the controversy. ${ }^{57}$

Wilson used religious, social, economic, and political arguments in his case for a dry utopia. He contended that

55. Vincent P. DeSantis, "American Politics in the Gilded Age," Review of Politics 25 (1963), 553.

56. On the political climate of the period, see Morton Keller, Affairs of State: Public Life in Late Nineteenth Century America (Cambridge, MA, 1977); H. Wayne Morgan, From Hayes to McKinley: National Party Politics, 1877-1896 (Syracuse, NY, 1969).

57. K. Austin Kerr, Organized for Prohibition (New Haven, CT, 1985), 35-65; Donald Barr Chidsey, On and Off the Wagon (New York, 1969), 53-56; Jack S. Blocker, Retreat from Reform: The Prohibition Movement in the United States, 1890-1913 (Westport, CT, 1976), 126; Sage, William Boyd Allison, 184-90. Wilson never supported the Prohibition party's presidential candidates. And although he was allied with Clarkson on prohibition, Wilson could not embrace Clarkson's attempts in 1892 to deny President 
drinking, especially among urban immigrants, constituted a threat to law and order and weakened the moral fiber of the nation. A product of a hardworking, nondrinking, and churchgoing environment, Wilson saw the large cities as citadels of sin and breeding grounds for drunkenness. Believing that the saloon system was an evil without any redeeming features, Wilson encouraged laws to achieve his goals. He favored the constitutional prohibitory amendment that Iowans approved in 1882 only to have the state supreme court disallow it on a technicality the next year. Eventually, the Republican-dominated legislature enacted a prohibition law. On July 4, 1884, the state became dry. ${ }^{58}$

In addition to his support of prohibition, Wilson strongly encouraged reading and writing. In fact, it was through his persistent and determined efforts that Fairfield obtained a library building. Enlisting Andrew Carnegie in the cause, Wilson donated the land and ultimately served as the library's president. This library was one of his proudest achievements. ${ }^{59}$

In 1888 Wilson's decision to seek a second term in the Senate generated some intraparty debate. Clarkson and Perkins were among those who opposed Wilson's reelection. Fortunately for the senator, his adversaries were neither united nor active, while Democrats showed little interest in the contest. Possible Republican challengers included Governor William Larrabee, ex-congressman and diplomat John A.

Benjamin Harrison renomination for a second term. See Stanley P. Hirshson, "James S. Clarkson. Versus Benjamin Harrison, 1891-1893: A Political Saga," Iowa Journal of History 58 (1960), 219-27; Clarkson to Allison, 26 February 1892, Allison Papers; and Ballard C. Campbell, "Did Democracy Work? Prohibition in Late Nineteenth Century Iowa: A Test Case," Journal of Interdisciplinary History 8 (1977), 87-116.

58. Newspaper clippings and Charles Beardsley to Wilson, 15 May 1882, Wilson Papers; Dan Elbert Clark, "The History of Liquor Legislation in Iowa, 1878-1908," Iowa Journal of History and Politics 6 (1908), 503-550. Excellent material on prohibition can be mined from the Temperance and Prohibition Papers (on microfilm), the James M. Comly Papers, and the Charles Dick Papers at the Ohio Historical Society. See also James B. Weaver to John P. St. John, 27 May 1888, John P. St. John Papers, Kansas State Historical Society, Topeka.

59. Wilson to James F. Wilson, Jr., 29 December 1891, Wilson Papers. 
Kasson, and former congressman William P. Hepburn. Wilson took no chances. Shortly before the General Assembly convened to choose the next senator; he established headquarters at the Kirkwood Hotel in Des Moines. There he donned his black suit and slouch hat, his "campaign uniform ... which always comes out when the Senator is running for office." To enhance his prospects, he revived Reconstruction-era maneuvers by waving the "bloody shirt" against the Democrats in general and issuing invectives against President Cleveland's pension bill vetoes and subservience to the South in particular. By these tactics, Wilson hoped to divert attention from himself and appeal to the old Radical faction of the party. ${ }^{60}$

On the evening of January 10, 1888, Iowa Republican legislators met in caucus and unanimously nominated Wilson for another term, as party loyalists rallied behind the incumbent. Several days later, the General Assembly voted overwhelmingly to return Wilson to the Senate. ${ }^{61}$ The Wilsonites had achieved another victory.

Wilson's reelection to the Senate coincided with the presidential restoration of the Republicans. Although he had favored Allison for the 1888 GOP nomination, Wilson wholeheartedly supported Benjamin Harrison, the Republican presidential standard-bearer, in his successful attempt to defeat Cleveland. Wilson rejoiced upon learning of Harrison's victory and immediately sought Iowa patronage from the new chief executive. He also backed the president's programs, including supervision of federal elections in the South, tariff protectionism, and purchases of silver. When Blaine challenged Harrison for the presidential nomination in 1892, Wilson, turning away from his former ally, publicly endorsed Harrison for a second term. The president's loss that year to Cleveland troubled Wilson, and over the next few years Americans debated the nation's tariff duties and currency

60. Chicago Daily Tribune, 6 January 1888; Sage, William Boyd Allison, 202-3; Briggs, William Peters Hepburn, 140-44; Clark, History of Senatorial Elections in lowa, 210-15; and pertinent information in the George D. Perkins Papers and the John A. Kasson Papers, State Historical Society of lowa, Des Moines.

61. 1888 Iowa House Journal, 123; Iowa State Register, 11 January 1888; Iowa City Daily Republican, 11 January 1888. 
system during a severe economic depression. The Democrats divided over the issue of silver coinage at a ratio of 16 to 1 with gold, and a group of western silver Republicans joined with the silver Democrats and Populists in that cause. The currency question failed to ignite in Wilson the passion it generated in others committed to bimetallism. In fact, for Wilson, the issue was neither a sacred dogma nor a symbol of revolt. ${ }^{62}$

In poor health by 1894, Wilson chose not to seek a third term and was succeeded in the Senate by Gear. That year Republicans gained a great congressional victory that heralded the beginning of a political realignment that would endure until the 1930s. Wilson retired to Fairfield, where he died just a month after completing his senatorial service. His body was interred in Fairfield's Evergreen Cemetery, thereby bringing to a close the career of a prominent Iowa politician. ${ }^{63}$

WILSON'S CAREER must be judged not by a model that others established for him but rather by the standard he set for himself. He also deserves to be measured by the standards and ideas then prevalent. Without question, his public ambitions were political, and to these he directed his energy and ability. In just eleven years he rose rapidly as a self-made man from being a poor harnessmaker to the chairmanship of the House Judiciary Committee. That experience gave him an appreciation for economy in government and faith in American institutions. A man of conviction and determination, Wilson once remarked, "Whatever strength I have comes from

62. Wilson to Benjamin Harrison, 3 March 1889, 22 June, 21 July 1892, Benjamin Harrison Papers, Library of Congress; J. Rogers Hollingsworth, The Whirligig of Politics: The Democracy of Cleveland and Bryan (Chicago, 1963); Horace Samuel Merrill, Bourbon Democracy of the Middle West, 18651896 (Seattle, 1967).

63. Fairfield Daily Ledger, 23, 24 April 1895; Midland Monthly, July 1895; Allison to Rollin J. Wilson, telegram, 23 April 1895, Wilson Papers. Useful insights into the period can be gleaned from Jean B. Kern, "The Political Career of Horace Boies," Iowa Journal of History 47 (1949), 215-46; Herman C. Nixon, "The Populist Movement in Iowa," Iowa Journal of History and Politics 24 (1926), 3-107; and materials on the Iowa Farmers Alliance in the Luman H. Weller Papers, State Historical Society of Wisconsin, Madison. 
one thing (i.e.) I always follow my convictions and am content to be patient in working them into results." ${ }^{\prime \prime 4}$

Wilson served on behalf of his constituents the needs of the nation. Intertwining the fortunes of the Republican party with his own and his prepossession for practical politics, he brought conservative leadership to the GOP during the Civil War, Reconstruction, and the Gilded Age on issues fraught with enormous political possibilities. He participated in many important events for over thirty years. Yet he was bored by interminable debate and angered by legislative obstruction; he retired from the House, rejected Cabinet offers, and returned to the political arena only to be overshadowed by Allison. In the meantime, he warned of the dangers of arbitrary executive power and held a Whiggish high regard for the constitutional restrictions on presidential power. In the end, Wilson thought that American politics would be greatly improved if contests could be carried on without regard to the possession of offices.

Wilson's strengths as a politician outnumbered his shortcomings. Of the latter, some are worthy of consideration. First, he erred badly in his opinions of certain individuals, including President Hayes. Second, Wilson was too quick to condemn the Cleveland administration, doing so in most cases for purely partisan propaganda. Third, while setting high standards for himself, he too conveniently overlooked Republican scandals, remaining reticent and forgiving of the greed and corruption that engulfed some of his colleagues. After eight years of a failed administration under Grant, Wilson was willing to reinstate the former president in office for a third term.

Wilson seemed at times a bundle of contradictions. He viewed the success of his opponents with suspicion and frequently camouflaged his own weaknesses with selfrighteousness. The Iowan yearned for responsibility but often hesitated to put his ambition to the test. He longed for tranquillity but had a strong sense of duty. Preferring a legislative role to that of an executive, Wilson shunned bombastic rhetoric, seeking instead to address audiences in measured tones.

64. Wilson to Clarkson, 13 November 1880, Garfield Papers. 
He was most comfortable with small groups of people and made friendships in many cases that proved lasting. Moreover, Wilson was a highly moralistic person who fell victim at times to the political culture of the period. Politically active in a post-Civil War society beset by a crisis of values, he was more inclined to conform than criticize.

Most of all, Wilson was an astute Iowa politician and a Republican loyalist. His close friend, Major Samuel H. M. Byers, a diplomat and poet, observed some of Wilson's qualities upon the senator's death when he said, "If the state of Iowa ever had a patriot, Senator Wilson was the man. He put Iowa above everything.... His abilities were those of a statesman, not a politician." 65 Byers touched on a significant aspect of Wilson's career. Historians, who have long neglected him, need to give more attention to describing and assessing Wilson's role in state and national politics.

65. Quoted from a newspaper clipping in a scrapbook of the Wilson Papers. 
Copyright of Annals of Iowa is the property of State of Iowa, by \& through the State Historical Society of Iowa and its content may not be copied or emailed to multiple sites or posted to a listserv without the copyright holder's express written permission. However, users may print, download, or email articles for individual use. 